\title{
Combining ability of maize grain yield under different levels of environmental stress
}

\author{
Leandro Vagno de Souza(1), Glauco Vieira Miranda(2), João Carlos Cardoso Galvão(2), \\ Lauro José Moreira Guimarães ${ }^{(3)}$ and Izabel Cristina dos Santos ${ }^{(4)}$
}

\begin{abstract}
(1)Dow Agrosciences, Rodovia Anhanguera, Km 344, Zona Rural, CEP 14680-000 Jardinópolis, SP, Brazil. E-mail: Ivsouza2@dow.com (2)Universidade Federal de Viçosa, Departamento de Fitotecnia, Avenida P.H. Rolfs, s/no, CEP 36570-000 Viçosa, MG, Brazil. E-mail: glaucovmiranda@ufv.br, jgalvao@ufv.br ${ }^{(3)}$ Embrapa Milho e Sorgo, Rodovia MG 424, Km 45, Caixa Postal 285, CEP 35701-970 Sete Lagoas, MG, Brazil. E-mail: lauro@cnpms.embrapa.br ${ }^{(4)}$ Empresa de Pesquisa Agropecuária de Minas Gerais, Avenida José Cândido da Silveira, no 1647, Cidade Nova, CEP 31170-000 Belo Horizonte, MG, Brazil. E-mail: icsantos@epamig.br
\end{abstract}

\begin{abstract}
The objectives of this work were to caracterize the tropical maize germplasm and to compare the combining abilities of maize grain yield under different levels of environmental stress. A diallel was performed among tropical maize cultivars with wide adaptability, whose hybrid combinations were evaluated in two sowing dates, in two years. The significance of the environmental effect emphasized the environmental contrasts. Based on grain yield, the environments were classified as favorable $\left(8,331 \mathrm{~kg} \mathrm{ha}^{-1}\right)$, low stress $\left(6,637 \mathrm{~kg} \mathrm{ha}^{-1}\right)$, high stress $\left(5,495 \mathrm{~kg} \mathrm{ha}^{-1}\right)$, and intense stress $\left(2,443 \mathrm{~kg} \mathrm{ha}^{-1}\right)$. None of the genetic effects were significant in favorable and intense stress environments, indicating that there was low germplasm variability under these conditions. In low and high stresses, the specific combining ability effects (SCA) were significant, showing that the nonadditive genetic effects were the most important, and that it is possible to select parent pairs with breeding potential. SCA and grain yield showed significant correlations only between the closer environment pairs like favorable/low stress and high/intense stress. The genetic control of grain yield differed under contrasting stress environments for which maize cultivars with wide adaptability are not adequate.
\end{abstract}

Index Terms: Zea mays, abiotic stress, breeding, diallel, drought.

\section{Capacidade de combinação da produtividade de milho em ambientes com diferentes intensidades de estresses}

Resumo - O objetivo deste trabalho foi caracterizar o germoplasma de milho e comparar a capacidade de combinação da produtividade do milho em ambientes com diferentes graus de estresse. Um dialelo foi realizado entre cultivares de milho tropical com ampla adaptabilidade, cujas combinações híbridas foram avaliadas em duas épocas de plantio, em dois anos. A significância do efeito ambiental mostrou que os ambientes foram contrastantes. Com base na produtividade, os ambientes foram classificados como: favorável $\left(8.331 \mathrm{~kg} \mathrm{ha}^{-1}\right)$; com baixo estresse (6.637 $\left.\mathrm{kg} \mathrm{ha}^{-1}\right)$; com alto estresse (5.495 $\left.\mathrm{kg} \mathrm{ha}^{-1}\right)$; e com intenso estresse $\left(2.443 \mathrm{~kg} \mathrm{ha}^{-1}\right)$. Nenhum dos efeitos genéticos foi significativo nos ambientes classificados como favorável e com intenso estresse, o que indica haver baixa variabilidade para as combinações genéticas nesses ambientes. Em baixo e alto estresse, os efeitos da capacidade de combinação específica foram significativos, o que mostra que os efeitos genéticos não aditivos foram os mais importantes, e que é possível selecionar pares de genitores com potencial para melhoramento. A capacidade geral de combinação e a produtividade de grãos apresentaram correlações significativas somente entre os ambientes mais próximos como favorável/baixo estresse e alto/ intenso estresse. $\mathrm{O}$ controle genético da produtividade de grãos difere em ambientes contrastantes quanto ao estresse para os quais as cultivares de milho com ampla adaptabilidade não são adequadas.

Termos para indexação: Zea mays, estresse abiótico, melhoramento, dialelo, seca.

\section{Introduction}

Breeding maize adapted to stressed environment was described as the primary cause of increased grain yield over the last seventy years in Iowa, USA. The interaction between maize productivity and plant density in the USA was explained using canopy and root system architecture by simulation studies, but the last trait with water capture had a direct effect on biomass accumulation and historical yield trends (Hammer et al., 2009).

It is estimated that $60 \%$ of agricultural producers worldwide live in areas under some type of abiotic stress, producing only 15 to $20 \%$ of global food (Ceccarelli, 1996). Thus, the development of cultivars adapted to abiotic stress conditions is of utmost importance for food security. 
A successful plant breeding program is directly related to the superiority of the new cultivars. Studies have shown that the average annual maize culture gain is around 2\%. Cardwell (1982) showed that the annual maize yield increase in Minnesota was $85 \mathrm{~kg} \mathrm{ha}^{-1}$, with $43 \%$ of this increase due to the introduction of new cultivars. Studies done by Castleberry et al. (1984) show that genetic gains are different across contrasting environments and that genetic gains are higher in environments that do not cause any type of stress. Thus, in order to improve plant breeding efficiency under stress conditions, parental selection must be based on results obtained in that specific environment.

Cultivars developed and selected under optimal environmental conditions are not adequate for a broad use under stress conditions (Ceccarelli, 1996). In fact, cultivars should be evaluated and selected in the region where they will be planted or in similar environments. It is, thus, necessary to characterize these environments, and determine the real conditions facing the cultivars to be indicated.

Progeny selection is one of the most important stages of a plant breeding program. Various methods are available for this selection, the main criteria being performance per se and combining ability, which can be classified as general or specific. General combining ability (GCA) is defined as the average performance of a parent in a series of hybrid combinations, whereas specific combining ability (SCA) is the difference in performance of certain hybrid combinations in relation to what would be expected, based on the general combining ability. The GCA is related with additive genetic effects and SCA with nonadditive genetic effects (dominant and epistatic). Diallel analyses are very common in maize breeding, and different strategies of diallel analyses are available (Oliveira Júnior et al., 1999; Silva et al., 2003; Miranda et al., 2008; Souza et al., 2008).
The objectives of this work were to identify tropical maize germplasm and to compare the combining abilities of maize grain yield under different degrees of environmental stress.

\section{Materials and Methods}

Maize cultivars AG 122, AL 25, BR 106, BR 205, and Z 8447 were selected from different maize breeding programs. These cultivars had satisfactory yield potential and were classified as widely adaptable (Table 1).

In order to evaluate the combinating ability of these cultivars, hybrid combinations were obtained by using a complete diallel, where each hybrid combination was represented by at least 50 maize ears.

Thirteen cultivars were assessed in total, including the possible hybrid combinations and three controls. The trials were carried out during 1999/2000 and 2000/2001, at Estação Experimental de Coimbra, MG, and at the Estação Experimental do Aeroporto, in Viçosa, MG, both of the Departmento de Fitotecnia, Universidade Federal de Viçosa (UFV). The trials done at Estação Experimental de Coimbra were established in October and November of 1999/2000 and 2000/2001, respectively, which is the most appropriate time for maize sowing in southeastern Minas Gerais, Brazil. Irrigation was used in the October 1999 trial, during the culture's drought phases. The assays carried out at Estação Experimental do Aeroporto started in December, in order to expose the crop to water deficit and to high temperatures over phenological stages 4 through to 9 (tassel emission to "hard" grains). The cultivars were evaluated in four environments in Coimbra (at $20^{\circ} 50^{\prime} 30^{\prime \prime} \mathrm{S}, 42^{\circ} 48^{\prime} 30^{\prime \prime} \mathrm{W}, 720 \mathrm{~m}$ altitude) and Viçosa (at $20^{\circ} 45^{\prime} 20^{\prime \prime} \mathrm{S}, 42^{\circ} 52^{\prime} 40^{\prime \prime} \mathrm{W}, 640 \mathrm{~m}$ of altitude).

The experimental design was in randomized blocks with two replicates. Each experimental plot contained

Table 1. Characteristics of the cultivars used as parents or controls.

\begin{tabular}{lllll}
\hline Cultivar & \multicolumn{1}{c}{ Type } & Cycle & \multicolumn{1}{c}{ Region indicated $^{(1)}$} & Kernel type \\
\hline AG 122 & Double hybrid & Early & South, Center, SP, MG, RJ, BA, MA, PI, TO, PA. & Semident \\
AL 25 & Variety & Semi-early & Brazil & Flint \\
BR 106 & Variety & Early & Brazil, except RS & Semident \\
BR 201 & Double hybrid & Early & Brazil, except RS & Semident \\
BR 205 & Double hybrid & Early & Southeast, Center, Northeast, PR, TO & Semident \\
P30F80 & Simple hybrid & Semi-early & South, Center, BA, MA, PI, SP, TO, PE, AL, ES, SE & Flint \\
Z 8447 & Double hybrid & Early & & Semident \\
\hline (1) States of: SP, São Paulo; MG, Minas Gerais; RJ, Rio de Janeiro; BA, Bahia; MA, Maranhão; PI, Piauí; TO, Tocantins; PA, Pará; RS, Rio Grande do Sul; \\
PR, Paraná; PE, Pernambuco; AL, Alagoas; ES, Espírito Santo; SE, Sergipe.
\end{tabular}

Pesq. agropec. bras., Brasília, v.44, n.10, p.1297-1303, out. 2009 
two 5-m rows, spaced $0.90 \mathrm{~m}$ apart with $0.20 \mathrm{~m}$ between plants, and an estimated final plant stand of 55,555 plants per hectare.

Combined variance and combined and individual diallel analyses were carried out for the trait grain yield $\left(\mathrm{kg} \mathrm{ha}^{-1}\right)$.

The methodology used to estimate the GCA and SCA effects was proposed by Griffing (1956) (method 4), using only the hybrid combinations. Correlations were made between the environment pairs for specific combining ability (SCA) and grain yield.

\section{Results and Discussion}

The effect of environment on grain yield $\left(\mathrm{kg} \mathrm{ha}^{-1}\right)$ was significant and showed that the environments showed contrasts (Table 2). During the period between germination and plantlet emergence in environment 1 (Coimbra, MG, October 1999), cool summer average temperatures between $15^{\circ} \mathrm{C}$ and $18^{\circ} \mathrm{C}$ were observed, but with the use of irrigation, crop performance was not affected. In environment 2 (Viçosa, MG, December 1999), cool temperatures occurred for five days during plantlet emergence, after which temperature increased in comparison to environment 1 . Similar conditions were found in environment 3 (Coimbra, MG, November

Table 2. Summary of the combined analysis of variance for grain yield (GY, $\left.\mathrm{kg} \mathrm{ha}^{-1}\right)$.

\begin{tabular}{|c|c|c|}
\hline Source of variation & DF & Mean square \\
\hline Blocks/environments & 4 & $112,955.3$ \\
\hline Cultivars (C) & (12) & $2,251,303.2^{\mathrm{ns}}$ \\
\hline Hybrid combinations (HC) & 9 & $1,745,413.5^{\mathrm{ns}}$ \\
\hline GCA & 4 & $504,832.0^{\mathrm{ns}}$ \\
\hline SCA & 5 & $2,736,640.0^{\text {ns }}$ \\
\hline Controls (Test.) & 2 & $4,990,673.8^{\mathrm{ns}}$ \\
\hline HC x Test. & 1 & $1,325,569.3^{\mathrm{ns}}$ \\
\hline Environments (E) & 3 & $159,904,629.1 * *$ \\
\hline $\mathrm{C} \times \mathrm{E}$ & (36) & $1,767,706.9 * *$ \\
\hline $\mathrm{HC} \times \mathrm{E}$ & 27 & $1,517,608.6^{*}$ \\
\hline $\mathrm{GCA} \times \mathrm{E}$ & 12 & $1,153,369.5^{\mathrm{ns}}$ \\
\hline $\mathrm{SCA} \times \mathrm{E}$ & 15 & $1,808,616.0^{*}$ \\
\hline Test. x E & 6 & $2,977,305.3 * *$ \\
\hline $\mathrm{HC} \times$ Test. $\mathrm{x} E$ & 3 & $1,599,395 \cdot 1^{\mathrm{ns}}$ \\
\hline Residue & 48 & $819,971.6$ \\
\hline Total & 103 & \\
\hline \multirow[t]{4}{*}{$\overline{\mathrm{GCA}}$} & Favorable environment & $1,067,545^{\mathrm{ns}}$ \\
\hline & Low stress & $560,784^{\mathrm{ns}}$ \\
\hline & High stress & $1,770,434^{\mathrm{ns}}$ \\
\hline & Intense Stress & $566,175^{\mathrm{ns}}$ \\
\hline \multirow[t]{4}{*}{ SCA } & Favorable environment & $1,001,629^{\text {ns }}$ \\
\hline & Low stress & $2,973,466^{*}$ \\
\hline & High stress & $3,773,179 * *$ \\
\hline & Intense Stress & $414,212^{\mathrm{ns}}$ \\
\hline
\end{tabular}

* $\mathrm{e}^{* *}$ Significant at 5 and $1 \%$ of probability by the $\mathrm{F}$ test. ${ }^{\text {ns Nonsignificant. }}$ DF, degrees of freedom.
2000). In environment 4 (Viçosa, MG, December 2000), two cool periods were observed - the first during germination and the second for five days shortly after plantlet emergence, where the highest limitations for the culture at stage zero (seed to emergence) occurred. However, the greatest differences among the environments were observed between stages 4 (at tassel emission) and 5 (at flowering and pollination).

The maximum temperature of environment 1 was below $30^{\circ} \mathrm{C}$, considered optimal for maize. In addition, irrigation in this environment provided the best conditions for crop development, a fact confirmed by the higher general grain yield average obtained in this environment $\left(8,331 \mathrm{~kg} \mathrm{ha}^{-1}\right)$. Hybrid combinations $\left(8,471 \mathrm{~kg} \mathrm{ha}^{-1}\right)$ and controls $\left(7,857 \mathrm{~kg} \mathrm{ha}^{-1}\right)$ produced the best yields (Table 3 ). In environment 4 , low water availability was observed with a daily average below $7 \mathrm{~mm}$ and a maximum temperature above $30^{\circ} \mathrm{C}$.

The occurrence of a cool summer after flowering (58 days after emergence) in low stress, and during flowering (60 days after emergence) in high and low stresses, resulted in a reduction of grain yield compared to the favorable environment. In low stress, average grain yield was $6,637 \mathrm{~kg} \mathrm{ha}^{-1}$ corresponding to a $20 \%$ reduction in relation to the favorable environment. In high stress, a 39\% reduction was observed, with an average of 5,495 kg ha-1. Maize requires a minimum of 350 to $500 \mathrm{~mm}$ of total rainfall. Daily consumption rarely exceeds $3 \mathrm{~mm}$ up to stage 7 (leaves), reaching $10 \mathrm{~mm}$ during the reproductive stages, mainly under high temperatures. Thus, the intense stress environment produced the lowest average grain yield of $2,443 \mathrm{~kg} \mathrm{ha}^{-1}$. In the same years and sites, Miranda et al. (2009) evaluated the genotype $\mathrm{x}$ environment interaction for popcorn on four dates of sowing, during two years, and found unfavorable and favorable environments for popcorn, according to sowing dates related to water deficit.

The environments were, thus, classified in relation to stress intensity, as follows: environment 1, favorable; environment 2, low stress; environment 3, high stress; and environment 4, intense stress. Maize productivity is associated with genotype, environment and genotype $\mathrm{x}$ environment interactions.

Tollenaar \& Lee (2002) studied the commercial maize yield in the USA and concluded that the genetic improvement in yield is associated neither with yield 
potential or heterosis per se, but with increased stress tolerance, which is consistent with the improvement in the genotype $x$ management interaction. Souza et al. (2009) evaluated the genetic variability and predicted genetic gain in the white maize landrace at Campos dos Goytacazes, RJ, Coimbra and Barbacena, MG. These sites were chosen for their soil and climatic differences. In Campos dos Goytacazes and Coimbra, the genetic variation of the white maize landrace could be used in selection cycles, and in Barbacena there was no significant genetic variance in grain yield. The authors concluded that the characters of the productivity component, such as plant density and number of plants with kernels, can produce indirect genetic gain for grain yield and are suitable for breeding; prebreeding of the maize landrace would be necessary before being used for breeding in the elite germplasm, and the difference among environments would produce specific responses in the progeny i.e., there would be progeny $x$ environment interaction.

In the USA, Duvick et al. (2004) reported that the yield increase was associated with increase in ears per 100 plants, leaf angle score, and stay-green score, and decrease in the anthesis-silking interval (ASI). Tollenaar \& Lee (2006) reported that the tassel size scores and yield increase was not associated with a change in maximum harvest index. Lee \& Tollenaar (2007) studied the physiological source of successful breeding strategies for maize grain yield, and concluded that the functional stay-green and the sink establishment dynamics still represent opportunities for yield improvements. One strategy for exploiting these opportunities is to incorporate trials of high plant population density into inbred line development programs.

The diallel study showed that no effects were significant under the favorable and intense stress environments, indicating that the additive and nonadditive genetic effects were similar (Table 2). For the low and high stress environments, SCA was significant, showing that the genetic effects of dominance were the most important, and that it is possible to select parents with breeding potential.

The hybrid combination $\mathrm{x}$ environment interaction was significant, which highlight a genotype $\mathrm{x}$ environment interaction and shows that the differences among the environments significantly influenced parental performance (Table 2).

The significance observed for the SCAx environment interaction shows that the nonadditive genetic effects and the SCA were significantly influenced by environmental changes.

In terms of the SCA averages and grain yield in the four environments, the most indicated hybrid combinations are BR $106 \times$ AL 25, with a SCA estimate equal to 516 and a grain yield of $6,174 \mathrm{~kg} \mathrm{ha}^{-1}$, and BR $205 \times$ AG 122 with a SCA of 740 and an average yield of $6,563 \mathrm{~kg} \mathrm{ha}^{-1}$, followed by Z $8447 \mathrm{X}$ AL 25 with a SCA of 419 and an average yield of $6,191 \mathrm{~kg} \mathrm{ha}^{-1}$ (Table 3).

Table 3. Grain yield averages (GY, $\left.\mathrm{kg} \mathrm{ha}^{-1}\right)$ and specific combining ability (SCA) estimates in four environments.

\begin{tabular}{|c|c|c|c|c|c|c|c|c|c|c|}
\hline \multirow[t]{2}{*}{ Cultivars } & \multicolumn{2}{|c|}{ Favorable $^{(1)}$} & \multicolumn{2}{|c|}{ Low stress ${ }^{(1)}$} & \multicolumn{2}{|c|}{ High stress $^{(1)}$} & \multicolumn{2}{|c|}{ Intense Stress $^{(1)}$} & \multicolumn{2}{|c|}{ Average } \\
\hline & SCA & $\mathrm{GY}^{(2)}$ & SCA & $\mathrm{GY}^{(2)}$ & SCA & GY & SCA & GY & SCA & GY \\
\hline Z8447xBR106 & -360 & $9,019 \mathrm{~A}$ & -774 & $5,907 \mathrm{~B}$ & 194 & $5,150 \mathrm{Bab}$ & 158 & $2,617 \mathrm{C}$ & -195 & 5,673 \\
\hline Z8447xAL25 & 455 & $8,935 \mathrm{~A}$ & 1342 & $7,671 \mathrm{AB}$ & -258 & $5,376 \mathrm{Bab}$ & 140 & $2,782 \mathrm{C}$ & 419 & 6,191 \\
\hline Z8447xAG122 & -98 & $8,541 \mathrm{~A}$ & -196 & $6,136 \mathrm{~A}$ & 576 & $6,907 \mathrm{Aab}$ & 81 & $3,087 \mathrm{~B}$ & 90 & 6,168 \\
\hline Z8447xBR205 & 4 & $8,512 \mathrm{~A}$ & -371 & $5,599 \mathrm{~B}$ & -511 & $5,674 \mathrm{Bab}$ & -379 & $1,868 \mathrm{C}$ & -314 & 5,413 \\
\hline BR106xAL25 & 499 & $9,144 \mathrm{~A}$ & 605 & $7,677 \mathrm{AB}$ & 1,179 & $5,873 \mathrm{Bab}$ & -217 & $2,004 \mathrm{C}$ & 516 & 6,174 \\
\hline BR106xAG122 & 477 & $9,281 \mathrm{~A}$ & 588 & $7,663 \mathrm{~A}$ & -2012 & $3,377 \mathrm{Bab}$ & -512 & $2,073 \mathrm{~B}$ & -364 & 5,598 \\
\hline BR106xBR205 & -616 & $8,056 \mathrm{~A}$ & -418 & $6,295 \mathrm{~A}$ & 638 & $5,883 \mathrm{Aab}$ & 571 & $2,398 \mathrm{~B}$ & 43 & 5,658 \\
\hline AL25xAG122 & -973 & $6,931 \mathrm{~A}$ & -1564 & $5,157 \mathrm{AB}$ & 321 & $6,389 \mathrm{Aab}$ & 350 & $3,118 \mathrm{~B}$ & -466 & 5,399 \\
\hline AL25xBR205 & 18 & $7,790 \mathrm{~A}$ & -382 & $5,979 \mathrm{AB}$ & -1242 & $4,681 \mathrm{Bab}$ & -273 & $1,737 \mathrm{C}$ & -469 & 5,047 \\
\hline BR205xAG122 & 594 & $8,527 \mathrm{~A}$ & 1,172 & $7,537 \mathrm{~A}$ & 1,114 & $7,735 \mathrm{Aa}$ & 81 & $2,455 \mathrm{~B}$ & 740 & 6,563 \\
\hline P30F80 & & $9,612 \mathrm{~A}$ & & $6,867 \mathrm{~B}$ & & $6,630 \mathrm{Bab}$ & & $2,610 \mathrm{C}$ & & 6,432 \\
\hline BR 201 & & $6,268 \mathrm{~A}$ & & $6,297 \mathrm{~A}$ & & $4,911 \mathrm{ABab}$ & & $2,907 \mathrm{~B}$ & & 5,096 \\
\hline AG 122 & & $7,693 \mathrm{~A}$ & & $7,502 \mathrm{~A}$ & & $2,840 \mathrm{Bb}$ & & $2,102 B$ & & 5,034 \\
\hline General average & & $8,331 \mathrm{~A}$ & & $6,637 \mathrm{D}$ & & $5,495 \mathrm{C}$ & & $2,443 \mathrm{D}$ & & 5,727 \\
\hline $\mathrm{CH}$ average & & 8,471 & & 6,562 & & 5,705 & & 2,414 & & 5,789 \\
\hline Control averages & & 7,857 & & 6,889 & & 4,797 & & 2,540 & & 5,521 \\
\hline $\mathrm{CV}(\%)$ & & 11 & & 14 & & 20 & & 27 & & 16 \\
\hline
\end{tabular}

${ }^{(1)}$ Means followed by equal capital letters in the lines, and small letters, in the columns, do not differ statistically by Tukey test at $5 \%$ probability. ${ }^{(2)}$ Does not differ by the $\mathrm{F}$ test, at $5 \%$ probability. 
In terms of the averages obtained in each environment, in a favorable environment, the hybrid combinations Z $8447 \times$ AL 25, BR 106 x AL 25, BR 106 x AG 122 and BR $205 \times$ AG 122 gave the highest SCA estimates and grain yield averages above $8,500 \mathrm{~kg} \mathrm{ha}^{-1}$. The hybrid combinations Z 8447 x AL 25, with a SCA estimate of 1,342 and a grain yield average of 7,671 kg ha-1, and BR $205 \times$ AG 122, with a yield of $7,537 \mathrm{~kg} \mathrm{ha}^{-1}$ and a SCA estimate of 1,172 , were the most promising for low-stress environments. For high stress, the most appropriate hybrid combinations were: Z 8447 x AG 122, with SCA 576, and yield of 6,907 $\mathrm{kg} \mathrm{ha}^{-1}$; BR $106 \times$ BR 205, with SCA 638, and yield of 5,883 $\mathrm{kg} \mathrm{ha}^{-1}$; and BR205 x AG 122, with SCA 1114 , and yield of $7,735 \mathrm{~kg} \mathrm{ha}^{-1}$. In the intense stress environment, hybrid combinations BR 106 x BR 205 and AL $25 \times$ AG 122, with SCA averages of 571 and 350 and grain yield of 2,398 and 3,118 $\mathrm{kg} \mathrm{ha}^{-1}$, respectively, were the most promising (Table 3 ).

The SCA and grain yield averages of the cultivars showed significant positive correlations only between the favorable $\mathrm{x}$ low-stress and high-stress $\mathrm{x}$ intense stress environment pairs (Table 4). Grain yield showed no significant correlations in the environment pairs favorable $\mathrm{x}$ high stress, favorable $\mathrm{x}$ intense stress, low stress $\mathrm{x}$ high stress and low stress $\mathrm{x}$ intense stress. SCA showed significant negative correlations in the contrasting environments favorable $\mathrm{x}$ intense stress and low stress $x$ intense stress. The absence of positive correlations between various environments for grain yield and especially the significant negative correlations observed for specific combining ability emphasize the importance of environment characterization, discriminating the favorable from the nonfavorable environments. If these differences are not taken into account, the results obtained at the final breeding phase, when the new cultivars are assessed, may be totally different from those expected, due to

Table 4. Correlation between grain yield (GY) and specific combining ability (SCA) across environments with contrasting stress intensities.

\begin{tabular}{|c|c|c|}
\hline Environments & GY & SCA \\
\hline Favorable x Low stress & $0,46^{*}$ & $0,92 * *$ \\
\hline Favorable x High stress & $0,14^{\mathrm{ns}}$ & $-0,14^{\mathrm{ns}}$ \\
\hline Favorable $\mathrm{x}$ Intense stress & $-0,27^{\mathrm{ns}}$ & $-0,62 * *$ \\
\hline Low stress $x$ High stress & $-0,23^{\mathrm{ns}}$ & $0,01^{\mathrm{ns}}$ \\
\hline Low stress $\mathrm{x}$ Intense stress & $-0,25^{\mathrm{ns}}$ & $-0,30^{*}$ \\
\hline High stress x Intense Stress & $0,44^{*}$ & $0,61 * *$ \\
\hline
\end{tabular}

the influence of the environment on the phenotypic performance and mainly on the parental combining ability, which would limit the genetic development of the culture. The genetic results obtained show that the selection must be carried out in specific environments and confirm the phenotype results. Silva et al. (2008) evaluated and estimated the genetic parameters for grain yield of two maize populations in two water deficit conditions. They concluded that the populations did not have sufficient genetic variation to be used in selection programs under water deficit conditions and that the agreement between the family performances was low under normal irrigation and water deficit.

These results show that the genetic control for grain yield differs according to the environment and defines the strategy for cultivar development and breeding methods, as reported by Atlin \& Frey (1989) and Tollennar \& Lee (2002). Thus, the type of genetic action appeared to be different under drought, with additive effects being more important in such conditions. The importance of additive effects increased with the intensity of drought stress. This suggests the need for drought-tolerance in both parental lines to achieve acceptable hybrid performance under severe drought. Good performance across stress levels can be achieved in tropical maize hybrids (Betrán et al., 2003). Based on the estimates of the SCA effects and grain yield averages, two alternatives may be available for parent selection. The first would be to consider the estimated averages of the SCA effects and grain yield obtained through the hybrid combinations across the environments. The second would be to consider the averages in each environment.

However, the results contrast with those obtained by Derera etal. (2008), who showed that the contribution of the genetic dominance effects was the most important in drought conditions. In such conditions, they found that only the general combining ability (GCA) variance had a significant effect on yield, indicating the predominance of additive effects. In nondrought environments, both GCA and SCA variances were significant for yield, indicating the importance of additive and nonadditive effects. Cardwell (1982) reported that the maize yield increase in Minnesota was largely due to the use of hybrid maize, making it evident that high hybrid maize yields can be obtained under favorable and unfavorable conditions. Thus, hybrid development and the application of inter-population breeding methods are of the utmost importance. 
The results show that when considering the SCA averages obtained in each environment, it is possible to identify superior hybrid combinations specific for different stress intensities; however, when considering the average performance in each environment, hybrid combinations with potential for specific environments cannot be selected.

For intense stress, one viable alternative would be the use of recurrent selection, since the general combining ability is linked to a high frequency of genes. A study by Monneveux et al. (2006) confirmed the effectiveness of recurrent selection under drought as a means of improving tropical maize source populations for performance under drought. The primary mechanism underlying these changes appears to be improved supply of assimilates to the ear at flowering, at the expense of tassel and stem growth.

Heterosis for grain yield in maize has been associated with heterosis for kernel number. Echarte et al. (2006) evaluated maize cultivars at three levels of water availability $(100,75$, or $60 \%$ of daily transpiration), during a period bracketing silking, and at two plant densities ( 6 and 10 plants $\mathrm{m}^{-2}$ ) without nutrient limitations, to generate a range of levels of resource availability per plant. They concluded that the heterosis for kernel set was associated with the heterosis for ear growth rate during the critical period for kernel set bracketing silking to varying degrees, and the extent of the association varied with the inbred line-hybrid combination and the level of resource available to the plants. Echarte et al. (2008) quantified the differences between an older and a newer maize hybrid in their response to nitrogen availability throughout the life cycle at both the leaf and whole-plant level. The reduction in grain yield in low $\mathrm{x}$ high $\mathrm{N}$ was greater in the older than in the newer hybrid. The hybrid $\mathrm{x} \mathrm{N}$ interaction for grain yield was attributable predominantly to a greater decline in the proportion of dry matter allocated to the grain in the older hybrid.

\section{Conclusion}

1. Commercial varieties with wide adaptability used in the diallel do not have the potential to be a germplasm source under conditions of intense stress.

2. Commercial germplasm with wide adaptation does not show an adequate performance, nor can it originate new populations for intense stress environments.

\section{Acknowledgements}

To Conselho Nacional de Desenvolvimento Científico e Tecnológico, to Coordenação de Pessoal de Nível Superior, and to Fundação de Amparo à Pesquisa do Estado de Minas Gerais, for financial support; to the students and technicians who contributed to the research of Programa de Milho at Universidade Federal de Viçosa.

\section{References}

ATLIN, N.G.; FREY, K.J. Breeding crop varieties for low-input agriculture. American Journal of Alternative Agriculture, v.4, p.53-28, 1989.

BETRÁN, F.J.; RIBAUT, J.M.; BECK, D.; GONZALEZ DE LEÓN, D. Genetic diversity, specific combining ability, and heterosis in tropical maize under stress and nonstress environments. Crop Science, v.43, p.797-806, 2003.

CARDWELL, V.B. Fifty years of Minnesota corn production: sources of yield increase. Agronomy Journal, v.74, p.984-990, 1982.

CASTLEBERRY, R.M.; CRUM, C.W.; KRULL, C.F. Genetic yield improvement of U.S. maize cultivars under varying fertility and climatic environments. Crop Science, v.24, p.33-36, 1984.

CECCARELLI, S. Adaptation to low/high input cultivation. Euphytica, v.92, p.203-214, 1996.

DERERA, J.; TONGOONA, P.; VIVEK B.S.; LAING, M.D. Gene action controlling grain yield and secondary traits in southern African maize hybrids under drought and non-drought environments. Euphytica, v.162, p.411-422, 2008.

DUVICK, D.N.; SMITH, J.S.C; COOPER, M. Long-term selection in a commercial hybrid maize breeding program. Plant Breeding Reviews, v.24, p.109-151, 2004.

ECHARTE, L.; ROTHSTEIN, S.; TOLLENAAR, M. The response of leaf photosynthesis and dry matter accumulation to nitrogen supply in an older and a newer maize hybrid. Crop Science, v.48, p.656-665, 2008.

GRIFFING, B. Concept of general and specific combining ability in relation to diallel crossing systems. Australian Journal of Biological Sciences, v.9, p.463-493, 1956.

HAMMER, G.L.; DONG, Z.S.; MCLEAN, G.; DOHERTY, A.; MESSINA, C.; SCHUSSLER, J.; ZINSELMEIER, C.; PASZKIEWICZ, S.; COOPER, M. Can changes in canopy and/or root system architecture explain historical maize yield trends in the U.S. corn belt? Crop Science, v.49, p.299-312, 2009.

LEE, E.A.; TOLLENAAR, M. Physiological basis of successful breeding strategies for maize grain yield. Crop Science, v.47, p.202-215, 2007.

MIRANDA, G.V.; SOUZA, L.V. de; GALVÃO, J.C.C.; GUIMARÃES, L.J.M.; VAZ DE MELO, A.; SANTOS, I.C. dos. 
Genetic variability and heterotic groups of Brazilian popcorn populations. Euphytica, v.162, p.431-440, 2008.

MIRANDA, G.V.; SOUZA, L.V. de; GUIMARÃES, L.J.M.; NAMORATO, H.; OLIVEIRA, L.R.; SOARES, M.O. Multivariate analyses of genotype $\mathrm{x}$ environment interaction of popcorn. Pesquisa Agropecuária Brasileira, v.44, p.45-50, 2009.

MONNEVEUX, P.; SANCHEZ, C.; BECK, D.; EDMEADES, G.O. Drought tolerance improvement in tropical maize source populations: evidence of progress. Crop Science, v.46, p.180-191, 2006.

OLIVEIRAJÚNIOR, A.; MIRANDA, G.V.; CRUZ, C.D. Prediction of F3 populations based on unbalanced diallel crossing systems. Pesquisa Agropecuária Brasileira, v.34, p.781-787, 1999.

SILVA, R.G.; GALVÃO, J.C.C.; MRANDA, G.V.; OLIVEIRA, E. de. Genetic control of the resistance to corn stunt. Pesquisa Agropecuária Brasileira, v.38, p. 921-928, 2003.

SILVA, R.G.; MIRANDA, G.V.; CRUZ, C.D.; GALVÃO, J.C.C.; SILVA, D.G. Estimativas de parâmetros genéticos da produção de grãos das populações de milho UFVM 100 e UFVM 200, submetidas a deficit hídrico. Revista Brasileira de Milho e Sorgo, v.7, p.57-67, 2008.

SOUZA, A.R.R. e; MIRANDA, G.V.; PEREIRA, M.G.; SOUZA, L.V. de. Predicting the genetic gain in the Brazilian white maize landrace. Ciência Rural, v.39, p.19-24, 2009.

SOUZA, L.V. de; MIRANDA, G.V.; GALVÃO, J.C.C.; ECKERT, F.R.; MANTOVANI, E.E.; LIMA, R.O.; GUIMARÃES, L.J.M. Genetic control of grain yield and nitrogen use efficiency in tropical maize. Pesquisa Agropecuária Brasileira, v.43, p.1517-1523, 2008.

TOLLENAAR, M.; LEE, E.A. Dissection of physiological processes underlying grain yield in maize by examining genetic improvement and heterosis. Maydica, v.51, p.399-408, 2006.

TOLLENAAR, M.; LEE, E.A. Yield potential, yield stability and stress tolerance in maize. Field Crops Research, v.75, p.161-169, 2002.

$\overline{\text { Received on April 8, } 2009 \text { and accepted on September 19, } 2009}$ 